\title{
5. The Child and Japanese National Trauma
}

\begin{abstract}
Chapter Five considers how the child became a pivotal component of post-World War II Japanese national identity, which is buttressed by a quasi-sacred belief in rapid national progress. The chapter contends that this competitive model of progress conceptually locks the child into an overdetermined fixation with national development. The inextricable entwinement of childhood and national progress led to powerful anxieties about the child when Japan's economy collapsed in what has become known in Japan as the 'Lost Decade', 1991-2001. The chapter reads the boom of child-centred 'J-horror' cinema around the millennial turn as an expression of widespread cultural anxieties that national progress was coming undone.
\end{abstract}

Keywords: Childhood, Progress, Japanese cinema, Lost Decade, National identity, World War II

Parallel to the Spanish horror films discussed in the previous section, the child characters of Japanese horror of the millennial turn problematize a narrow ideal of national progress. At the approach of the turn of the millennium, the release of RINGU (Hideo Nakata, 1998)' ignited a transcultural obsession with the uncanny child. The film incited a franchise that remains one of Japan's most commercially successful domestic film products. ${ }^{2}$ Sadako,

1 For the sake of clarity, I will refer to the original film throughout as 'Ringu', and the franchise as a whole as 'Ring.' In fact, the title 'Ringu' is somewhat problematic as it was not the original translation given to the film's title (which was initially simply 'Ring'). The Romanization 'Ringu' came in use to differentiate Nakata's film from the American remake.

2 In fact, Mark Cousins suggests that RINGU was 'the most commercially successful [film] ever released in [Japan]' $(2013,354)$; however, this claim is inaccurate, particularly two decades after the film's release. But, as Mark Kermode (2000) reinforces, at the time of release, RinGU

Balanzategui, J., The Uncanny Child in Transnational Cinema: Ghosts of Futurity at the Turn of the Twenty-First Century, Amsterdam University Press, 2018.

DOI: $10.5117 / 9789462986510 / \mathrm{CHO} 5$ 
the terrible aggressor of RINGU, has become perhaps the most recognizable horror icon of the new century: a strange but telling paradigm for this moment of global transition, considering that she functions as a harbinger for the collapse of chronological progress. Sadako wears a long, tattered, white dress evocative of the tarnished burial gowns adorned by the vengeful spirits of premodern Kabuki and Noh plays. Furthermore, like the grotesque female spirits depicted in Edo-era ukiyo-e, Sadako's face is obscured by her lank black hair, suggesting but never entirely revealing an unspeakably abject visage. Sadako haunts her victims from within the well in which she died, recalling the ancient Japanese folktale 'Banchō Sarayashiki' ('The Dish Mansion at Banchō') in which a young woman, thrown into a well by her Samurai master and left to die, returns to haunt him from her watery sepulchre.

Yet, while she evokes traditional Japan, Sadako uses technologies such as VHS tapes, televisions, cameras, and computers as the vessels for her supernatural curse. Even her use of technology, when considered on its own terms, speaks of unstable, liminal temporalities: when Sadako first infected a VHS videotape in late 1998, VHS - a triumph of Japanese technological innovation - dominated the home entertainment sector. Yet, DVD had emerged only a year before, and by the time RINGU attained global popularity, VHS was on the brink of obsolescence. Sadako's videotape curse thus surfaces not only in the midst of millennial transition, but in the fold between analogue and digital storage. Emerging from the grainy analogue snow of the VHS image, Sadako advances towards her victims slowly and deliberately, recalling the measured motions of Noh dance, yet her contorted, painfully spasmodic movements suggest those of Butoh, an intentionally abject form of performance art that emerged in the 196os, in part as a protest against Noh and other highly structured, traditional forms of Japanese dance. Sadako's eruption through the television screen which projects her image encapsulates in potent form all of these temporal dissonances, as her previously spectral being suddenly takes on corporeal form within her victim's own present, physical space. Clearly, this eerie creature is polysemically and disruptively asynchronous - as are all the uncanny children from Japanese horror of the millennial turn.

was Japan's most successful domestic horror film, with a worldwide gross of approximately \$13 million. Mitsuyo Wada-Marciano (2009) points out that the sequel RINGU 2 (Nakata, 1999) doubled RINGU's sales, and the franchise continues to expand, with recent sequels SADAKO 3D and SADAKO 3D 2 (Tsutomu Hanabusa, 2012; 2013) earning a combined worldwide gross of approximately $\$ 20$ million. 
Sadako has become the synecdoche for the uncanny child on a grand scale. She appeared initially in the original novel Ring by Koji Suzuki (1991) (which Suzuki has followed with four sequels); and has since featured in eight Japanese feature films to date (as well as two successful American remakes, an American reboot, and a Korean remake), two Japanese television series and a telemovie, eleven manga, two videogames, a radio drama, and in 2014 joined Sanrio's extremely popular 'Hello Kitty' franchise, which released merchandise such as dolls, stickers, mugs, and pencil cases depicting Sadako emerging from the well in which she died or crawling through a television screen (the most iconic moments of the original film). After the immense success of RINGU, so-called 'J-horror' became metonymic of an entire national cinema. As I outline in this chapter, at the cusp of the new millennium, childhood in Japan became implicated in anxieties surrounding the 'Lost Decade' - a time of economic stagnation after decades of successful postWWII progress - in such deep and complex ways as to enforce a wholesale consideration of what childhood 'means' to Japanese national identity.

\section{The Horror Genre in a Japanese Context}

Many of Japan's most respected and well-known contemporary directors, including Takashi Miike, Sion Sono, Kiyoshi Kurosawa, Takashi Shimizu, and Ringu's Hideo Nakata worked primarily within the horror genre in the final years of the 1990s and first decade of the 2000s. Many of these directors secured their global auteur status through their internationally successful horror releases, and continue to work within the genre or employ horror aesthetics in more conventionally prestigious genres such as period drama and art films (as seen, for instance, in Miike's critically acclaimed period drama HARA-KIRI: DEATH OF A SAMURAI [2011]). Thus, such generic boundaries are often blurred in a Japanese context. As a result, critically acclaimed horror films tend to be assured a place in canonical paradigms of Japanese national cinema - a phenomenon which particularly dominated Japan's film industry during the J-horror boom of the millennial period. In fact, unlike in Spain, the recent influx of globally successful Japanese horror films do not represent a sudden horror 'golden age' following many decades of being relegated to the margins - horror has long been a central and dominant presence in the landscape of Japanese film. However, as Mitsuyo Wada-Marciano (2009) has noted, even though many films produced during Japanese cinema's golden age during the 1950s and 196os are now taken for granted as canonical horror films - including UGETsU (Kenji Mizoguchi, 1953), Ghost Story of YotsuYa (Nobuo Nakagawa, 1959), KwAIDAN (Masaki 
Kobayashi, 1964), and ONIBABA (Kaneto Shindô, 1964) - they were not necessarily considered as such at the time of their production and original release.

Despite the fact that such films of the 1950s and 196os centre upon their eerie atmosphere and an intention to ignite dread and terror in audiences, as Wada-Marciano suggests, they were usually considered art, period and/ or folktale films (known as minwa-mono) at the time of their release (2009, 35-36). Such prestige connotations relate to how these films were marketed for Western film festivals such as the Cannes and Venice Film Festivals, but also reflect their association with time-honoured Japanese theatre traditions Kabuki and Noh ${ }^{3}$ - which themselves draw on ghost folklore known as kaidan - indicating that in Japan, horror aesthetics are not considered to be marginal or inferior. It could in fact be argued that after the successful export of some of these horror-suffused art films to international festivals and audiences, the deployment of horror aesthetics in period pieces and artistic mediations of historical trauma became a distinctive technique of Japanese cinema in which directors took great pride. ONIBABA and KWAIDAN are both foundational instances of this framework, both being supernatural period pieces that raise the spectre of premodern Japan to consider postWWII traumas allegorically. Both films played at the ${ }_{1965}$ Cannes film festival, with KWAIDAN being awarded the Special Jury Prize. Ghost tales are ultimately a central facet of Japanese reflections on pre-modernity and ancient traditions - often used to express more recent historical tensions, as in KWAIDAN and ONIBABA - which goes some way towards explaining the prevalence of horror aesthetics in both low and high Japanese film genres. Thus, in Japan, horror's symbolic power and its subsequent ability to work through sociocultural anxieties has long been explicitly recognized.

While supernatural horror has long held an important place in Japanese culture, during the millennial turn and throughout the first decade of the 21st century, the specific subgenre designated J-horror - the transnational classification for these recent Japanese films - came to reshape the landscape of global horror film. As Wada-Marciano points out, the prefix ' $\mathrm{J}$ ' is 'thoroughly connected with the media distributor's strategy of marketing

3 For instance, UGETSO is based on Ueda Akinari's seminal Edo period ghost story collection Ugetso Monogatari (first published in 1776). The film won the Silver Lion Award for Best director at the 1953 Venice Film Festival. GHOST STORY of YotsuyA is a direct retelling of a famous folktale Yotsuya Kaidan, and is based in particular upon the nineteenth-century Kabuki version of the story written by Nanboku Tsuruya. KwAIDAN is an anthology of different ghost tales, drawn from Lafcadio Hearn's collection Kwaidan: Stories and Studies of Strange Things. This film was nominated for the Best Foreign Film at the Academy Awards in 1965, and was awarded the Special Jury Prize at the Cannes Film Festival. 
their product both inside and outside Japan' $(2012,29)$. Subsequent to the release of RINGU, J-horror films began to generate global recognition: as Chi-Yu Shin (2009) suggests, the international success of J-horror was sparked in part by London-based VHS and DVD publisher Tartan developing and globally positioning its 'Asian Extreme' label, which soon led to blockbuster Hollywood remakes of particularly popular films such as RINGU (THE RING, Gore Verbsinki 2002) and Ju-ON (Takashi Shimizu, 2002) (remade as THE GRUDGE, Shimizu, 2004). As a result, J-horror tropes and aesthetics quickly came to suffuse Hollywood horror generally. Such global influence in turn injected J-horror with a particularly heightened domestic cultural currency. For instance, in 2002, the year in which the American remake of RINGU was released, a ritual burial ceremony was held for Sadako in Tokyo to commemorate her passage from a Japanese to an American context - an acknowledgement that, in buying the rights to the RiNG films, Hollywood had on some levels claimed ownership of Sadako. ${ }^{4}$

This strong cultural currency ensures that J-horror's uncanny children have a more direct relationship with mainstream culture than those of the American and Spanish horror films. As both Chika Kinoshita (2009) and Thy Phu (2010) suggest, the term 'J-horror' does not denote simply a nationalized film genre but, to use Kinoshita's term, more of a 'movement' $(2009,104)$. During the shift into the 21st century, a series of ideological and structural contortions were reshaping Japanese culture, many of which spiralled from the bursting of the bubble economy - the effects of which will be explored in more detail below. As Wada-Marciano points out, the stagnation of the economy in the 1990 s resulted in significant restructuring of the film industry. As she suggests, the Lost Decade ushered in a 'reconfiguration at all levels of production, distribution, and reception' (Wada-Marciano, 2009, 16) underpinned by the rapid uprising of digital technologies and home viewing. In fact, she contends that 'J-horror grew out of the specific context of the contemporary Japanese film industry - the disintegration of the studio system and a levelling of competition, even increasing affiliations among "major" and "independent" film productions' (Wada-Marciano, 2009, 18).

The uncanny children that populate J-horror function as expressions of the unease surrounding such industrial and cultural shifts. These figures play out a frightening dissolution of the previously unquestioned ideological braiding of childhood with national identity, and thus the child's growing up

4 The ceremony was held at LaForet Museum, Harajuku; Ring author Koji Suzuki was in attendance (Landry, 2015). 
with national progress. The horrors of the uncanny children in many ways exceed the fictional realm of the films in which they appear, exposing the magnitude of the cultural work they perform: since the beginning of the 21st century, the characters of J-horror have invaded theme parks, city streets, and even sporting matches. A key horror set piece in many J-horror films consists of a technologically mediated image of the child-ghost drawing ever closer to the horrified spectator (diegetic and otherwise), before finally escaping the bounds of her technological housing to overwhelm the human subject: a particularly thrilling theme when depicted in real-life amusment attractions or events. For instance, Sadako has been the subject of a parade at Shibuya crossing (Muir, 2012), threw the first pitch at three major baseball games at Tokyo Dome, and has been the subject of five walk-through horror attractions at indoor theme park Sega Joypolis in Odaiba, Tokyo. ${ }^{5}$ This pervasive cultural performativity goes some way towards elucidating the powerful and lasting cultural influence of the uncanny child in Japan.

\section{The Internal Alien}

Because J-horror was such a ubiquitous pop-cultural phenomenon of the millennial transition, much insightful criticism ${ }^{6}$ has been written about this explosion of transnationally popular Japanese horror films. Yet surprisingly, aside from nuanced analyses by Karen Lury (2010) and Valerie Wee (2013) - the insights of whom I build upon in this section - to date this work has largely elided or understated the significance of the uncanny child, which, along with haunted technologies, is the most tellingly new commonality that underpins this assemblage of films. Much of the scholarly discourse about millennial J-horror focuses on the figure of the onryo (vengeful ghosts, usually female) or broader category the yūrei (ghost), and suggests that the monstrous spectres of millennial J-horror are primarily a continuation of the adult female ghosts featured in postwar art-horror (such as the aforementioned GHOST STORY OF YoTsUYA), themselves carried over from Japanese traditional art and kaidan (YoTsuYA being a direct retelling of one such folktale) (Balmain [2008], Blake [2008], Hand [2006], McRoy [2005;

5 For a report on a recent Sadako Joypolis attraction, see Lynzee Lamb (2013).

6 See in particular Colette Balmain (2006; 2008), Linnie Blake (2008); Richard Hand (2006), Chika Kinoshita (2009), Bliss Cua Lim (2009), Adam Lowenstein (2009; 2015), Karen Lury (2010), Jay McRoy (2005; 2008), Thy Phu (2010), Ramie Tateishi (2003), Mitsuyo Wada-Marciano (2009; 2012), and Valerie Wee (2011a; 2011b; 2013). 
2008], and Wee [2011a]). While the legacy of the vengeful female onryō looms over millennial J-horror, the child characters in these films are constituted of a new set of ideological and aesthetic motivations.

While the onryō and yürei are clearly major influences upon contemporary J-horror children (most of which are female), another important precedent to these figures is the eerie, knowing child of Japanese fantastic literature. Awareness of this grounding sheds much light on the cultural and textual mechanics of these characters, while also exposing the extent to which they modulate the long entrenched onryō/yürei archetypes. As Susan Napier (1995) has demonstrated in her work on Japanese fantastic fiction, the eerie child has figured heavily in the Japanese imaginary since the shift to modernity represented by the Meiji Restoration (1868). ${ }^{7}$ In the literary fiction she analyses, Napier describes a trope she designates the 'internal alien': a being, often a child or associated with childhood, who embodies inner psychic turmoil incited 'not by some alien outside force but through some frightening power inside [the protagonist's mind]' (Napier, 1995, 110). Across the examples Napier analyses, the internal alien exists at the interface between the ' $I$ ', the 'Other', and the collectivity at the same time as it exists between the past, present, and future (Napier, 1995, 110-128). She suggests that 'it is this polysemic potential which is so disturbing and enthralling to the reader' (Napier, 1995, 97). Emerging as it did following Japan's tumultuous transition to modernity, the literary trope of the creepy child who thematically and symbolically defies its proper place is deeply bound up with anxieties about national progress: a key feature of millennial J-horror children.

As Napier demonstrates, while the internal alien appears in a great deal of literary fiction post Restoration, ${ }^{8}$ a formative example appears in the short story by Natsume Sōseki from his collection Ten Nights' Dreams (first published in 1908). In the 'Dream of the Third Night', a man is walking through a forest at night with a six-year-old child on his back. The man

7 As is charted in the work of Anne Allison (1996), Napier (1995), Brian Platt (2005), Stefan Tanaka (2004), and many others, 1868 is commonly held as the date of the Meiji Restoration, as it was during this year that practical imperial rule was restored under Emperor Meiji, and Japan's political structure become configured and consolidated under his rule. The period spanned 1868-1912, and, during this time, Japan shifted from a feudal economy to a market economy, underwent a rapid process of industrialization, opened to Western trade, and strengthened its military. The period thus represented an extremely rapid process of modernization as Japan started to establish itself as a significant global agent.

8 Some works Napier analyses as part of the 'internal and ideological alien' trend include Kappa (Akutagawa 1927), Inter Ice Age 4 (Abe 1958), 'Agwhee the Sky Monster' (Ōe 1964), and The Pinch Runner Memorandum (Ōe 1976) and a number of works in Haruki Murakami's oeuvre. 
is aware that the child is his own, and also that the child is blind, but, in a hopeless undermining of adult agency and progress, he knows nothing else, not even to where he is walking or why. Even though the man knows the child is his son, he is afraid of him, for 'with this weird creature on my back, I felt something horrible was about to happen to me' (Sōseki, 200o, 10). As the man aimlessly trods ever onwards through the forest, the child remarks 'I will be heavier soon' (Sōseki, 2000, 10). The forest grows denser and darker, but, in the darkness, the child begins to reflect 'like a mirror, every tiny thing in my past, present, and future' (Sōseki, 2000, 11) to the point at which the man 'couldn't stand it anymore' (Sōseki, 2000, 11). Finally, as they stop under a tree, the child tells his 'father' that it has been '100 years since you killed me here!' (Sōseki, 2000, 13); it suddenly dawns on the man that he once killed a blind man under this very tree, a memory he has long since repressed. As he 'realized for the first time that I was a murderer, suddenly the little one on my back became much heavier than before, like a jizō stone child' (Sōseki, 2000, 13).9

The internal alien thus exists at the interface of the man's interior and exterior worlds: the child upon the man's back is the prosthetic vessel for the trauma and guilt he has until now refused to acknowledge consciously. Napier illuminates the multilayered ways eerie moments of recognition such as this are shared by the reader:

Reactions [to the horror] can range from intellectual admiration of and pleasure in the intensity of aesthetic effect [...] to the enjoyable frisson of terror that the reader vicariously experiences. [...] Underlying these obvious emotions [...] are more subtle and complex ones, most importantly the sense of excitement stemming from the liberation of sublimated fears and taboos. (1995, 96)

I suggest that the uncanny children of J-horror represent a contemporary remodelling of the internal alien. This figure has clear parallels with the American uncanny children analysed in Section One, resonating with Freudian myths about childhood's simultaneous entwinement with and distance from the inner depths of the adult psyche. Indeed, as Napier points out, the internal alien trope is connected with shifting ideas about selfhood

9 A 'jizō' is a bodhisattva or Buddhist 'saint' who helps others reach paradise by providing them with enlightenment and insight into their own lives, and is also a protector of children. Jizō is frequently represented throughout Japan as a small, childlike stone statue. For a detailed discussion of jizō, see Jan Chozen Bays (2002). 
throughout the Japanese transition to modernity, as premodern notions of the Japanese self came into contact with Western notions of identity: 'the fantastic Other may be seen as an important means by which postRestoration Japanese began to construct a Westernized sense of self [...] working out their explorations of the self against such textual elements as dreams, ghosts, monsters and dopplegangers' (Napier, 1995, 97). As Nina Cornyetz and J. Keith Vincent have shown in their examination of the history of psychoanalysis in Japan, Freudian psychoanalysis was introduced in Japan in 1912 and spawned a vibrant body of scholarly and cultural Japanese commentary and debate (2010, 3-5).

Freud-inflected notions of childhood as a crucible for adulthood's darkest repressed secrets reverberate in millennial, cinematic incarnations of the internal alien - particularly because the seminal American films of the early 1980 s considered in Chapter One are clear influences on millennial J-horror. Yet, as is indicated by Sōseki's tale, the internal alien functions in a more direct and embodied way than the uncanny children of American horror film, rendering clear and overt some of the complex symbolic mechanisms charted in the first section of this book. Perhaps it is partly because of the internal alien's potent intensification of Freud-influenced mythologies of childhood that this figure, as represented in J-horror, resonated so powerfully with Western audiences and became so conducive to American remakes in the early 200os. Like the internal alien in Sōseki's tale, the millennial J-horror child raises within adult characters - and viewers - an uncomfortable combination of fear stemming from a seemingly external source, and deep, internal psychic guilt and dread.

These affects are directly related to the sociocultural tensions permeating Japan at the liminal moment represented by the transition into the 21st century, tensions which parallel those surrounding the nation's rapid shift to modernity during and post Restoration. Nowhere more than Japan is the child so anxiously defined as a receptacle for national futurity according to the processual condition of growing up: as Lury suggests, in Japan, the child tends to symbolize 'the continuation of the nation state itself. The child acts to stabilize the inherent instability of modernism. [...] [a]nd seemingly [embodies] the potential for progress' (2010, 26). As will be explored in detail in the next chapter, the uncanny children of J-horror rail against this linear mode of temporality, disassembling the central ontological pillars that have long delineated childhood in Japan. The current chapter proceeds to examine the sociocultural contexts that fostered these millennial anxieties about childhood's subversive potential in Japan. 


\section{The Lost Decade and the Collapse of Progress}

In Japan, the period from the late 1990 s into the 2000 s was particularly fraught due to the Lost Decade, ${ }^{10}$ as the rapid economic growth of the $1960 \mathrm{~s}$ until 1989 suddenly slumped dramatically. Scholars in Japan and around the globe ${ }^{11}$ are still picking apart the ruins of the Lost Decade to determine its causes. The economic recession and subsequent stagnation resulted in wholesale changes to the structure of employment and industry in Japan, as previous models of lifelong employment within a single company have shifted with the increase of flexible, short-term contracts. The reconfiguration of employment has such far-reaching socio-ideological consequences that Anne Allison has characterized it in terms of the 'liquidization' of work and life structures $(2013,8)$. The bursting of the economic bubble thus had just as potent symbolic effects on Japan's national identity as it did tangible ones. As Allison states, 'in liquefied Japan a change in the logic of work seeps into everyday relationality: relations once valued for their sturdiness in space (staying in one company or neighbourhood for decades) and durability over time (lifelong marriages, group memberships, and jobs)' (2013, 8).

The anxieties surrounding this liquidization of seemingly solid spatial and temporal structures are related to the ways in which Japanese cultural identity has become cleaved to notions of national progress. Of course, the quest for progress is intertwined with the national ideology of most countries, however, as Napier points out: 'what makes Japan unique is the remarkable involvement at every level, on the part of the government, private citizenry, business, and educational institutions, in a highly conscious ideology of progress' (1995, 142). Japan's rather astonishing socioeconomic development following the nation's traumatic World War II defeat and subsequent Allied Occupation has long been held as a model for progress to be admired and emulated. As Napier puts it, postwar Japan has 'become something of a myth if not a full-blown fantasy' $(1995,2)$, and the epic qualities of Japan's postwar success story further injected the Lost Decade with the aura of a catastrophic downfall. Fletcher and von Staden explain that 'the experience of the Lost Decade has been traumatic for Japan. [...] Observers no longer claimed that Japan was "number one"'(2012, 275). They further state that 'the effects of the economic stagnation linger as the nation has not found a

10 In fact, this term is often revised to be 'the two Lost Decades', as Japan struggles to overcome this period of economic stagnation.

11 See Miles Fletcher and Peter von Staden (2012); Zuzana Stuchlíková (2012); Christopher Wood (1992); and David Weinstein, A. K. Kashyap, and Hamada Kōichi (2011). 
way out of its economic purgatory of slow growth over the past two decades' (Fletcher and von Staden, 2012, 275). Narratives of rapid national progress started to disintegrate throughout the 1990s, resulting in a wavering of the national confidence that had been successfully reassembled post war. The sociocultural collapse represented by the Lost Decade is particularly traumatic considering the extent to which Japan was required to repress or side-step its own past in order to adopt Westernized modes of progressive time consciousness, a repudiation of Japan's own cultural identity with roots in the Meiji Restoration of 1868 but further enforced throughout the Allied Occupation. Thus, Japan's Westernized, capitalistic progress and the economic rewards reaped through it were particularly high stakes.

In fact, from the time of the Meiji Restoration onwards, the quest for modernity, while overtly successful, has been underpinned by an unstable series of dichotomies. As Kevin Doak elucidates, 'modernity was defined in a variety of ways (and therefore tended toward obscurity): at times it represented a foreign influence - the West; at other times it referred to the Meiji state and its ideology of "civilization and enlightenment"' (1994, xvi). Narratives of rapid national progress attempted to reconcile this discordant constellation of principles, and, in some ways, uneasily suppressed them. Following Japan's traumatic defeat in World War II, fixations with progress were resurrected with deepened exigency and impetus, yet became even more overdetermined due to an inherent association with Japan's victimization: following the bombings of Hiroshima and Nagasaki in 1945, Japan's surrender and the subsequent Allied Occupation (1945-1952), progress became characterized as a valorous quest to overcome the nation's victim status. Yet, this emphasis on valiant progress surged firmly in the opposite direction from reflection on the multilayered extent of Japan's trauma. Involved in this renewed preoccupation with progress and futurity was an avoidance of culpability for the nation's own part in the war. Some disturbing cultural memories of wartime itself were thus quickly repressed and obfuscated.

Yoshikuni Igarashi (2000), Beatrice Trefalt (2003), and Bruce Suttmeier (2010) have demonstrated that accounts of Japanese aggression and violence during the war only began emerging in Japan in the late 196os and early 1970s, and even then in micro-form. As Suttmeier explains: 'for over two decades, the Japanese remembered the war largely through scenes of domestic deprivation and suffering, scenes that acknowledged the horrors of war even as they allayed the central anxieties concerning Japanese wartime activities' (2010, 31). Suttmeier elucidates this disavowal through a discussion of the 'triumphant' return in 1972 of Japanese solider Shōichi Yokoi, who had been hiding in a jungle in Guam for the previous 28 years, believing the 
war to be ongoing. His discovery and return to Japan was met with great fascination, and he became a media sensation. While Yokoi was initially valorized for his tenacity and fortitude - qualities that effectively paralleled the dominant discourse on Japan's postwar resilience - he gradually became a much more ambivalent figure. He delivered conflicting accounts about what happened to the two comrades who perished while living with him in the jungle, arousing suspicions about the circumstances of their deaths, and his persistent habit of referring to 'his Majesty the Emperor' excavated the memory of extreme prewar nationalism and Japanese wartime atrocities. Suttmeier suggests that, while Yokoi was initially perceived as 'the image of a victimized, resilient Japanese citizen', this impression was 'increasingly clouded by darker, more threatening scenes that spoke to an aggressive, brutalizing legacy' (2010, 32).

Such undercurrents of suppressed guilt continue to tug at Japanese notions of progress, particularly in recent years following the collapse of the bubble economy now that the veil of rapid progress has worn thin. The Japanese government continue to enact controversial and ambivalent responses to the war. In March 2017, Prime Minister Shinzo Abe's cabinet released a statement approving the use of the 'Imperial Rescript on Education' - issued by Emperor Meiji in 1890 - in Japanese classrooms. Children would recite this edict in school to pledge their allegiance to the Emperor and Japanese nation. The Imperial Rescript was declared null and void after WWII because its celebration of patriotism and national loyalty over individual subjectivity was thought to underpin Japanese military aggression. ${ }^{12}$ In 2013, the Osaka mayor at the time, Torū Hashimoto, claimed that wartime sex slaves (euphemistically known in Japan as 'comfort women') were necessary to ease the suffering and tension experienced by Japanese soldiers, ${ }^{13}$ and in December 2013, Prime Minister Abe visited Yasukini Shrine, which includes among its honourees fourteen convicted war criminals. ${ }^{14}$ In his discussion of Hashimoto's statements, Walden Bello suggests that such actions indicate that Japan 'has yet to come to terms with its actions in World War II' (2013, n.p.). The uncanny child in J-horror tends to raise these tensions in abstracted form: as will be detailed in the next chapter, the child is often characterized as a misunderstood victim before suddenly being exposed as a monstrous aggressor in a climactic twist. In all cases, the J-horror child disturbs narratives of progress and the status of victimhood, 
exposing the long-suppressed guilt and trauma that haunts contemporary Japan. The J-horror movement thus suggests that the Lost Decade forced the unease underlying ideologies of progress to surface, impelling a renewed interrogation of Japan's investment in progress and the uneasy relationship with the nation's past that lurks beneath mythologies of rapid national advance.

\section{Modernity and Childhood}

The J-horror child's disassembling of coherent, progressive time is deeply frightening in a Japanese context because the child sustains the linear logic at the core of conceptions of modernity and progress. As Stefan Tanaka explains, in Japan the child has become:

a site where the ambiguities and contradictions of modernity are ameliorated into a coherent whole personified through the child. [...] Childhood has become a symbol for several aspects of modernity: of a new progressive society, one looking forward to a seemingly better future; of temporariness, that idealized past or originary state that must be guided and transformed; and of immanence, the constant regeneration of that pure originary state. $(1997,22)$

Education for children was central to the national project of industrial and economic advancement during the Meiji Restoration, a project which was exhumed following the traumatic ruptures of WWII, albeit aligned along exigent new axes. The emergence of childhood as a distinct social category in Japan is inherently bound up with Japan's rapid shift to modernity.

Although influenced by many factors, the Meiji Restoration was largely sparked by Japan's opening up to Western trade with the arrival of the American navy led by Matthew C. Perry in 1853. This 'Arrival of the Black Ships', as it is known in Japan, exposed the nation to the most advanced of Western technologies. Subsequently, the Meiji period involved a highly conscious process of catching up with the West's technological developments: one of the most central shifts, as Morris Low points out, was that 'the Japanese literally had to learn to live by the clock' $(2009,134)$. Intrinsic to the swift transition to modernity were 'new ideas about time. Time became less rooted in nature and more closely aligned with machines and clocks' (Low, 2009, 134). Most central to this new living by the clock' was the movement away from a heterogeneous, plural time consciousness to a homogenous, socially unified temporal model driven by an ideal of collective 
linear progress. As Naofumi Nakamura explains, 'people in the Edo period (1500-1867) lived by what is called a variable hour system, which arbitrarily established that sunrise was 6 a.m. [...] and sunset was 6 p.m'. $(2002,14)$, a localized model of time which tied communities to the immediate conditions of their environment.

The Meiji Restoration saw the gradual introduction of a fixed hour system, the Gregorian calendar, and the Western Common Era model. As Tanaka points out, 'the significance of this new time is that it is abstract; it opened up the possibility for the transformation of myriad communities that had somehow coalesced into a "Japan" into a unified nation-state that is rational, scientific and efficient' (2004, 6). Greenwich Mean Time was officially sanctioned in 1888 , finalizing the process whereby Japan's time consciousness was integrated into the Western model. This new model of homogenous, national time quickly became embedded into the national consciousness in large part due to the carefully managed punctuality of the new, heavily populated train network, as 'people were forced to experience time in minutes, which they had never even considered before; if they were even a minute late, they would miss their train' (Nakamura, 2002, 16).

A reconfiguration of the concept of childhood was at the heart of the nation's temporal overhaul. By embodying futurity, the child cohered the new model of homogenous national continuity. Tanaka suggests that, in premodern and early modern Japan, children 'did not exist as future citizens, but as members of their locale. Childhood was not a unifying category that represented [...] an early stage of linear growth' $(1997,25-26)$. Prior to the Meiji shift to modernity, childhood was a diverse category associated with the particular seasonal cycles and working habits of the communities in which children grew up. This pluralism was rapidly stripped back during the Meiji Restoration, as the child became constituted as a unitary social category upon which the linear development of the nation was inscribed. As Kathleen Uno states, since the Meiji Restoration:

national salvation depended upon the socialisation of ordinary Japanese children. [...] most advocates of Japan's progress expected that private and municipal day-care centres would function as the allies of adult members of households, public schools, and other state-sponsored organizations in shaping children who would loyally serve the needs of national advancement and the imperial state. $(1999,8)$

Uno explains that for centuries leading up to the Meiji period, the Japanese family was structured around the $i e$ system, which ties the family 
to household dynasties. Children were essential to the continuation and immortality of the $i e$ : intergenerational progression, and thus investment in the child as a vessel for the successful continuation of the family, was an underpinning facet of the $i e$ structure. However, as intimated by Tanaka's comments above, the child did not represent a specific social unit and future national citizen; instead children functioned as receptacles for plural and localized forms of cross-generational futurity.

The ie structure underwent rapid change throughout the 2oth century, particularly following the Allied Occupation, as families became increasingly structured along Western lines. The family quickly became positioned as a social institution grounded by the central aim to socialize and educate children in service of the nation's future, rather than that of specific ie dynasties. A number of J-horror films analysed in the next chapter, particularly Ju-ON (Shimizu, 2002), lament the falling away of the extended community support and individual agency represented by the $i e$ structure. This is realized through depictions of small and toxically claustrophobic family units that disintegrate or tear each other apart, almost literally. Since the mid 1990s, Japan has had one of the world's lowest birth rates, with an average below 1.5 children born to a woman during her lifetime, ${ }^{15}$ another contributing factor to heightened anxieties about children and changing family dynamics in the late 199os.

In conjunction with the diminishing of the ie structure, central to the Meiji Restoration was the dismantling of Japan's feudal class system and the restructuring of communities in order to facilitate the process of rapid catch-up industrialization. This necessitated the repositioning of the child as not just a symbol of futurity for individual ie units, but for the entire nation. As Brian Platt puts it:

Japanese leaders during the early decades of the Meiji period (1868-1912) believed that the source of Western power and the key to Japan's national survival in the face of Western imperialism lay in the nation-state's capacity for mobilizing human resources. When they set about creating institutions to accomplish this goal, they recognized the particular importance of the school, which extended the project of mobilization to Japanese children. In turn, they opened up the child to public inquiry, generating within an emerging mass society a new awareness of childhood. [...] the modern concept of childhood was 'created' in the context of Japan's encounter with modernity. (2005, 965-966) 
This investment in the child as a vital sociocultural unit that must be effectively mobilized for rapid national progress escalated as the 2oth century progressed. The research of Roger Goodman (2000), Platt (2005), and Uno (1999) has revealed that daycare and school institutions rapidly became ubiquitous throughout the 2oth century, as urbanization resulted in groups of children roaming the streets, no longer employed with physical labour in service of the $i e$. This new anxiety started to consume modern Japanese leaders: in 1925, the Home Ministry's Social Bureau Chief went as far as to declare that 'the social weaknesses regarding children are the root of all social problems' (cited in Platt, 2005, 979). As Uno elucidates, 'if idle children grew up to be useless as workers, soldiers, and citizens [...] the nation would face a dismal future' $(1999,17)$. She further suggests that 'heightened concern for the character of children as future citizens established a basis for receiptivity to day-care centres', in large part because 'progress-minded Japanese came to see day-care centres as a means of cultivating habits of industry and economy, which would boost national productivity by resocializing a group of morally deficient citizens' (Uno, 1999, 17). Instilling patriotic and dutiful morals in children through school and even daycare systems became of primary importance, as the future success of Japan's industrial, technological, and ideological revolution was contained within them.

In alignment with this repositioning of the child to become the nucleus of the modernization process were the significant ideological reforms of Japan's education system during the Meiji period. The previously mentioned Imperial Rescript on Education (1890) was an officially sanctioned nationalized system of education, which, as Norma Field (1995) and Tanaka (1997) point out, explicitly positioned education as a gradual ascendance through a hierarchical system of knowledge and loyalty with the Emperor at the apex. Furthermore, Gerald Figal (1999), Tanaka (1997), and Tateishi (2003) point to education ideologue Tetsujirō Inoue's discourse on 'monsterology', which emerged in tandem with the Rescript and sought to remodel the curriculum to eliminate reference to supernatural folklore in favour of a more rational ideology in line with that of the West. Figal explains that monsterology aimed to 'attack obstinate beliefs at their roots and [argued] that this eradication of superstition (meishin taiji) was instrumental for the constitution of a healthy, modern Japanese state' (1999, 87). Tateishi expands: 'coded as illogical and chaotic, and thus antithetical to the project of modernisation, such elements were targeted as the embodiments of those qualities that needed to be eliminated in the name of progress' (2003, 296). 
This new curriculum based upon nationally sanctioned models of both Westernized rationality and Japanese patriotism was tied to the inculcation of the child into the incipient model of globally positioned, linear national time. As Tanaka states:

Inoue [describes] the space of childhood, a temporal site in which deferred work, the acquisition of knowledge, is not considered wasted time, but an asset more important than material resources. [...] By placing a value on time, Inoue is sacralising the child [...] Inoue, who is considered a conservative ideologue, is working within a progressive linear concept. The child who goes to school does not represent uselessness but deferred gratification, improvement, functionalization, and rationality. $(1997,33)$

Thus, post Restoration and throughout the first half of the 2oth century, the child became the locus through which new temporal and ideological paradigms were tested and played out, becoming tied to the relentlessly forward-looking chronology of modern time consciousness: in effect, the child's growing up became coiled to the 'growing up' of the nation itself.

\section{The Child and Postwar Consciousness}

In the years subsequent to World War II, the emotional valences that tied childhood to national development became increasingly polyphonic, as the project of reestablishing a distinctly Japanese identity from the ruins of the war and Japan's forced surrender became symbolically intertwined with the victimized child. Julie Rauer eloquently explains that the war resulted in a traumatic tearing of Japan's national identity: 'tragically splintered by defeat, subjugation, humiliation, and inconceivable horrors - unable to command a return to a unified monolithic persona, the ordered cerebral imperative and societal dignity of pre-nuclear innocence [...] World War II left indelible stains on the Japanese psyche' (2005, n.p.). After the war, images of the traumatized, scarred faces and bodies of women and children became embedded in the Japanese cultural consciousness. Lowenstein suggests that the image of the victimized woman became a potent postwar symbol of suffering and hardship that played into mythologies of Japan's victimization, a vision of trauma that also functions as a disavowal of responsibility (2005, 86). Lowenstein's assertion is reinforced by the research of Lisa Yoneyama, who states that 'the memories of Hiroshima [...] [sustained] at least in the dominant historical discourse, a national victimology' $(1999,13)$, and that 'postwar Japanese womanhood became fully implicated in sustaining the 

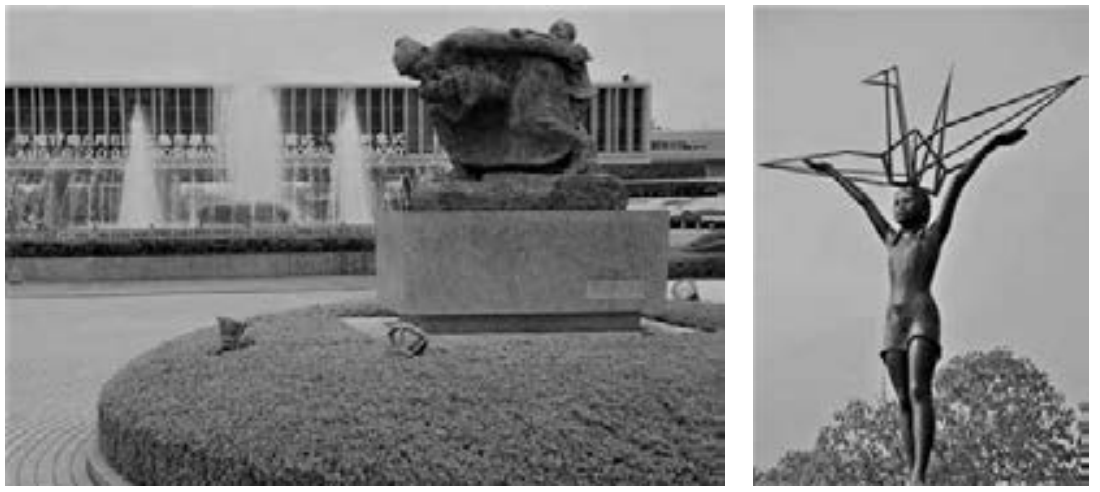

Figure 12. Left: Statue of Mother and Children During the Storm, Hiroshima Peace Park. Bronze, Shin Hongo, 1960; photograph by Fg2. Right: Children's Peace Monument, Hiroshima Peace Park. Bronze and Concrete, Kazuo Kikuchi and Kiyoshi Ikebe, 1958; photograph by Lewan Parker. The child on top of the monument represents Sadako Sasaki holding a large paper crane.

myth of national innocence and victimology' (1999, 38). The child became bound up in such mythology in particularly affective ways. In fact, images of orphaned children and of widows holding their children amongst the ruins of devastated cities became some of the most potent signifiers of Japan's postwar suffering and victimization. ${ }^{16}$

The image of the suffering child has become one of the key defining features of the Hiroshima Peace Park and Museum. Two significant sculptures at the Peace Park are the Statue of Mother and Children During the Storm and The Children's Peace Monument (Fig. 12), which depicts Sadako Sasaki, a young girl who died of radiation-induced leukaemia. Sasaki has since become the most recognizable symbol of the postwar valiant victim: on her deathbed, she endeavoured to fold one thousand paper cranes in an effort both to survive and to promote world peace. When she died before finishing this task, fellow students finished folding the cranes for her. The story of 'Sadako and the Thousand Paper Cranes' has attained mythic proportions in Japan, having been retold in numerous films, television programmes, and children's books. ${ }^{17}$ Thousands of origami cranes are placed around

16 See, for instance, the photograph of the terrified woman hiding in a cave with her children, taken during the Battle on Saipan island (Robertson, 1944), and the image of a charred mother and child on the streets of Tokyo following the 'Operation Meetinghouse' bombing in 1945 (Ishikawa, 1945).

17 For instance, the children's novel Sadako and the Thousand Paper Cranes (Eleanor Coerr 1977) and shortened illustrated version Sadako (Coerr and Ed Young 1993), Children of the Paper Crane: The Story of Sadako Sasaki and Her Struggle with A-bomb Disease (Masamoto Nasu 1991), and the animated film ON A PAPER Crane: TOMOKo's Adventure (Arihara Seiji 1994). 


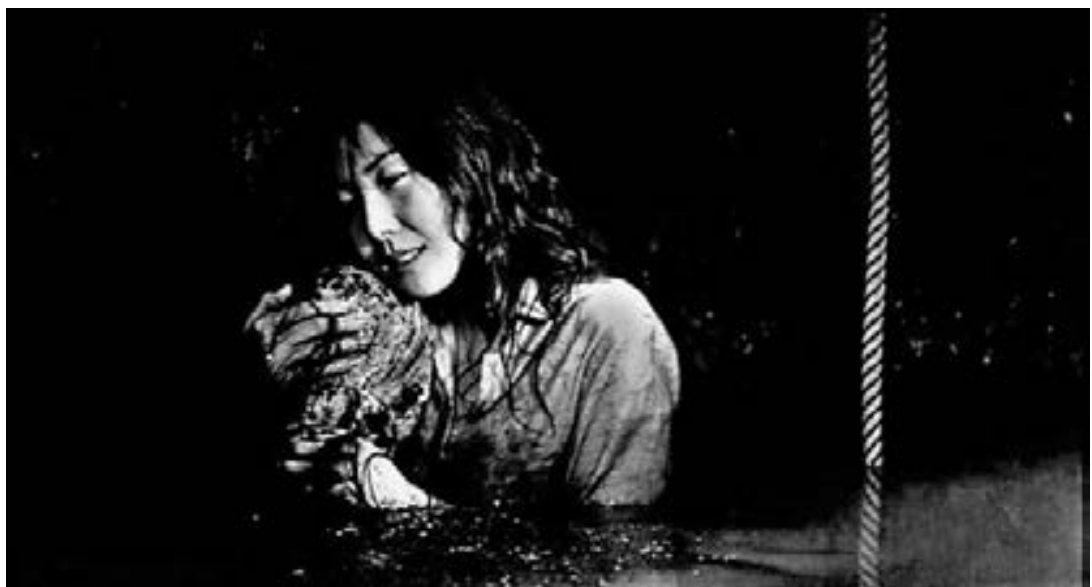

Figure 13. Reiko holds Sadako's decaying corpse to her breast in RINGU.

The Children's Peace Monument in honour of Sasaki each day. An entire section of the Hiroshima Memorial Museum is dedicated to Sasaki and other child victims of war, in which some of her paper cranes are on display. The most intensely affective part of the museum - as is emphasized by its positioning near the exit and dim lighting ${ }^{18}-$, this section also displays a burnt lunchbox, tricycle, and school uniform; children's drawings depicting their experiences of wartime trauma; and children's remains, such as hair and charred skin.

It is surely no coincidence that the archetypal J-horror child shares Sasaki's first name, a pointed reference to Sadako of RINGU's monstrous undoing of the valiant victim myth. RINGU seems to have reached a cathartic conclusion once the protagonist, Reiko, discovers Sadako's decaying corpse within the well in which she died. At this moment near the end of the film, Reiko clutches Sadako's corpse to her breast and begins to cry, accompanied by the swelling of warm, melancholy music (Fig. 13). Yet, while the film positions this sequence as Sadako's redemption - as the monstrous, violent ghost is at this moment domesticated into a helpless victim -, her status as a wronged victim is overturned in the climactic scene, when she emerges through Reiko's ex-husband Ryuji's television screen to kill him, acting out her curse even though he helped to uncover the circumstances of her murder and exhume her corpse. The scene also indicates that Sadako will continue to spread her curse throughout Japanese society indiscriminately,

18 At the time of writing, the museum is undergoing renovations, so it remains to be seen if this layout will remain. 
regardless of whether or not people like Reiko and Ryuji honour her memory or attempt to restore her humanity.

By the later decades of the 2oth century, the extremely successful and rapid manner whereby Japan had reclaimed economic and cultural independence had come to define Japan's postwar identity, and the pressure upon the child - both as concept and lived experience - had become acute. As Field (1995) and Allison (1996) have shown in their examinations of Japan's education system, part of Japan's extreme postwar success can be attributed to the locking of childhood into an increasingly linear system of national advancement in which education leads almost seamlessly into future employment. Writing in 1992 and drawing on conclusions from research conducted in the late 1980 os and early 1990 (the nascent emergence of the Lost Decade), Field explains that 'school and work are becoming increasingly continuous, such that the goals of education fail to suggest even a modicum of autonomy from the goals of the economy' (1995, 62). Field discusses the wider implications of this system on childhood, pointing to such materials as cofounder of Sony Masaru Ibuka's instructional child development books Why age zero? Life is decided at age zero (1989) and The Fetus is a Genius: Life begins before birth (1992), to outline the extent to which child development was seen to function in tandem with the capitalist progress of the nation throughout the 1980s and early 1990s. She suggests that the pressurized and claustrophobic ways in which children were hemmed in to this process has 'produced suffocating conditions over the past several decades' (Field, 1995, 62).

Allison reinforces Field's work, suggesting that:

the post-war educational model in Japan exceeds being 'merely' a school system and extends into a regime of test-taking that produces and centers the Japanese self. [...] [I]t is academic performance that has increasingly become the common standard of value in the economy. This means that in the marketplace of careers and jobs, it is the test scores and schools attended as youths that operate as the currency of exchange for adults. (1996, xvii)

It is important to emphasize that both authors write at the beginning of the Lost Decade, which had begun reshaping Japanese economic and social structures by the time both works were published. ${ }^{19}$ Thus, Field's and Allison's works provide valuable insight into the stifling entwinement of childhood 
and national progress as Japan approached long-term economic stagnation, in turn illuminating the extent to which a breakdown in national progress logically became associated with a failure in childhood development. ${ }^{20}$

\section{Progress Dismantled: The Strange-changed Child of the Lost Decade}

Central to this perceived meltdown of the fusion of childhood and national progress were two seemingly contradictory, yet intersecting, moral panics. The first was the 'discovery' in Japan of child abuse, which, until the 1990s, was considered to be a feature of Western modernity that Japan had managed to escape. Up until the late 1980 s, it was widely believed that the absence of child abuse in Japan set it apart from the West (Yoshiko Ikeda, 1995), and 'the apparent absence of abuse was generally explained in terms of the stability of the Japanese family, community, and wider society' (Goodman, 2000, 160). As Goodman points out, the discovery that child abuse occurred with regularity in Japan was in fact a result of clarifications and changes to the definition of what constituted abuse, after a number of surveys and the introduction of the U.N. Convention on the Rights of the Child (brought forth in the mid 1990s and ratified in Japan in 1998, the same year that RINGU was released). Nevertheless, amongst the ruptures of the Lost Decade, the sudden realization that Japan was not immune to child abuse became characterized as a concern that modern Japanese family and community structures were coming undone.

Spiralling from the discovery of child abuse was increasingly focused attention on the pressure placed upon the child in school. The intense education system previously celebrated as the locus of Japan's postwar

20 Although she does not make a connection to the horror films that emerged during the period (having presumably written her essay just prior to their emergence), Andrea G. Arai's 'The Wild Child of 1990s Japan' (2006) presents an insightful discussion of the simmering anxieties surrounding children and their relationship to educational and social structures in the mid 199os, focusing in particular on Princess Mononoke (Hiyao Miyazaki, 1997). First published in 2000, Arai finishes her essay with the questions:

How will the mass-mediazation of [images of wild children] interact with the new socioeconomic and historical concerns of the nation in the twenty-first century? How will these once again add to the reconfiguring of this site of the child in Japan, and how will 'the child' be positioned to make up for the deficits at the more crucial level of the representative force of the nation? How will this affect the social realities of the historical subjects themselves? $(2006,232)$

Arai suggests the extent to which the child was embroiled with anxieties about epochal shift represented by the transition into the 21st century, while raising some questions that I hope this section will start to address. 
success became cause for concern, particularly in the wake of research by sociologists such as Field that revealed the extent to which school children were suffering from physical and mental health issues as a result of stress. ${ }^{21}$ As Lury puts it, such revelations presented 'evidence that the national project was questionable, even malign' $(2010,27)$. Anxiety that Japan's school system was on the brink of disaster was reflected in the widespread emergence in the popular imagination of the term gakkyū hōkai (classroom collapse, the breakdown of order in the classroom). The phenomenon even became the subject of a best-selling book by teacher-turned-social commentator Ryoichi Kawakami, titled Gakkō Hōkai (School Collapse, 1999). The mythos of the resilient valiant victim had swirled around the child since the end of the war, yet ideas surrounding Japan's victimization and subsequent rising up from the ashes of the war - via the figure of the industrious child - had always positioned this victimization as the result of an external force that could be overcome with hard work. This new discourse on widespread child abuse and extreme pressure on students repositioned the child as a previously unacknowledged victim of Japanese society, eroding the boundaries between traumas inflicted from without and those that emerge from within.

The second but related moral panic revolves around a perception that childhood was mutating incomprehensibly, a panicked response to a string of violent juvenile crimes throughout the 199os and into the early 2000s. As Arai outlines, Kawakami and other Japanese commentators have described this fear as kodomo ga hen $d a$ (the strange-changed child, or the child is turning strange): in fact, Arai points to an informal collection of essays published by Kawakami in 1995 bearing this title, which 'describe how the Japanese child (much like the nation itself) had become unknowable and unrecognizable' $(2013,186)$. Professor of criminal psychiatry and social commentator Akira Ishii expresses the sudden shift in attitude towards modern family structures that accompanied the increase in juvenile crime: 'The breakdown of community and family traditions in modern Japan has seen [a rise in juvenile] crime without clear motives' (cited in Kakuchi, 2003, n.p.). One of the worst of these shocking crimes was a double murder committed by a fourteen-year-old from Kobe, known in the media as 'Boy A', who beheaded an eleven-year-old boy and killed a ten-year-old girl at his

21 Field (1995) cites a survey of Japanese grammar school children from 1990, which showed that $63.2 \%$ of children suffered high cholesterol, $36.2 \%$ from ulcers, $22.1 \%$ from high blood pressure, and $21.4 \%$ from diabetes. She refers to reportage of high levels of stress-related hair loss, eczema, and constipation. 
junior high school. The crimes were accompanied by lengthy notes, which referred to the murders as 'the beginning of the game' and justified them as social vengeance, claiming it was 'compulsory education which formed me, an invisible person' (Wetsch, 2005, n.p.). As a result of this vicious and unsettling crime, the age of criminal responsibility was lowered from sixteen to fourteen in 2000. Expressing oft-repeated sentiments of the time, Prime Minister Ryutaro Hashimoto questioned on national television 'Where did we go wrong?' and politician Shizuka Kamei claimed in despair 'Adults should be blamed for this' (Lev, 1997, n.p.). Of these strange-changed children, Kawakami lamented in a personal interview with Arai 'We can't get through to these children, they're incomprehensible (tsujinai; wakaranai) and we don't have a clue what they're thinking' $(2013,186)$.

A range of similar murders occurred in $2000,{ }^{22}$ the very year the age of criminal responsibility had been lowered in an effort to deter such crimes. In 2003, a twelve-year-old boy pushed a four-year-old from the roof of a shopping complex, resulting in the child's death: in response to the crime, the Asia Times reported that 'Shock and soul-searching gripped Japan' and quoted a businessman who lamented 'Whatever has happened to the peaceful and harmonious Japan we knew?' (Kakuchi, 2003, n.p.). The above are just some in the long list of violent juvenile crimes that occurred in Japan from the mid 199os to the mid 200os, most of which, as reported by the media, seemed shockingly incomprehensible. A constant cycle of media reportage emerged detailing the ways in which previously normal, calm children became possessed by kireru (sudden fits of rage). More shocking still was that the biggest rise in violent juvenile crime was acts committed by children under the age of fourteen. Not only did this moral panic about juvenile crime have a wide reach throughout Japan, but the phenomenon was frequently reported on in global media, further dissolving former pride in the child-centred national project: with headlines such as 'Juvenile Crime No Longer Rare in Japan' from the American Broadcasting Corporation (Litke, 2003), and 'Youth Violence Has Japan Struggling for Answers' from The Washington Post (Faiola, 2004).

These vessels for the future, held up as a symbol of national pride and rapid progress for so long in Japan, were turning strange in ways that could not be understood or contained. As Arai suggests, 'the child problem displaced the troubles of economic downturn and the fissures the downturn opened

22 A fifteen-year-old boy who had been bullied at school stabbed three people to death; a seventeen-year-old boy hijacked a bus, which led to the death of one woman; and another seventeen-year-old turned himself into the police after killing an elderly woman. 
up in national identification onto the young' $(2016,7)$. Yet, underlying this monstrous mutation was a delayed recognition of children's long-standing victimization: as is evident among much reportage of the kodomo ga hen da or kireru phenomenon in Japan, it was believed that children were finally enacting their violent revenge upon a society that had oppressed them in service of Westernized modes of capitalistic progress. The proliferation of child-centred horror films during the millennial turn is symptomatic of this multilayered cultural trauma, and represents a way for Japanese audiences to acknowledge and work through it, in similar ways to the internal alien in Sōseki's tale who rouses his father's intermingled guilt and trauma, yet on a collective scale. As will be seen in Chapter Six, the multivalent traumas raised by the J-horror uncanny child are deeply bound up with adult guilt associated with the sudden realization that the child's suffering stems from within Japan's cultural cocoon: a result of long-entrenched fixations with progress, productivity, and futurity.

\section{Works Cited}

Abe, Kobo. Inter Ice Age 4. Trans. Dale Saunders. 1958. New York: Perigee Books, 1981. Print.

Akinari, Ueda. Ugetsu Monogatari, or Tales of Moonlight and Rain. 1776. Trans. and Ed. Leon M. Zolbrod. London: George Allen \& Unwin Ltd., 1974. Print.

Akutagawa, Ryunosuke. Kappa. 1927. Trans. Geoffrey Bownas. London: Peter Owen Publishers, 2009. Print.

Allison, Anne. Permitted and Prohibited Desires: Mothers, Comics and Censorship in Japan. Berkeley: University of California Press, 1996. Print.

-.Precarious Japan. Durham: Duke University Press, 2013. Print.

Arai, Andrea G. 'Notes to the Heart: New Lessons in National Sentiment and Sacrifice from Recessionary Japan.' Global Futures in East Asia: Youth, Nation and the Economy in Uncertain Times. Ed. Ann Anagost, Andrea Arai, and Hai Ren. Stanford: Stanford University Press, 2013. 174-196. Print.

—.'The Wild Child in 199os Japan.' Japan After Japan: Social and Cultural Life from the Recessionary 199os to the Present. Ed. Tomiko Yoda and Harry Harootunian. Durham: Duke University Press, 2006. Print.

-.The Strange Child: Education and the Psychology of Patriotism in Recessionary Japan. Stanford: Stanford University Press, 2016. Print.

Balmain, Colette. 'Inside the Well of Loneliness: Towards a Definition of the Japanese Horror Film.' Electronic Journal of Contemporary Japanese Studies. 3 May (2006): n.p. Web. 30 Sep. 2014. 
-.Introduction to Japanese Horror Film. Edinburgh: Edinburgh University Press, 2008. Print.

Bays, Jan Chozen. Jizō Bodhisattva: Guardian of Children, Travelers and Other Voyagers. Boston: Shambhala Publications, 2002. Print.

Blake, Linnie. Wounds of Nations: Horror Cinema, Historical Trauma and National Identity. Manchester: Manchester University Press, 2008. Print.

Bello, Walden. 'The Hashimoto Controversy and Japan's Failure to Come to Terms with its Past.' Foreign Policy in Focus, Institute for Policy Studies. 22 May (2013). Web. 27 Oct. 2014.

'China protests at Japanese PM's latest WW2 shrine tribute.' TheGuardian.com, The Guardian News and Media. 17 Oct. (2014). Web. 30 Dec. 2014.

Cousins, Mark. The Story of Film. London: Pavilion, 2013. Print.

Doak, Kevin. Dreams of Difference: The Japan Romantic School and the Crisis of Modernity. Berkeley: University of California Press, 1994. Print.

Faiola, Anthony. 'Youth Violence Has Japan Struggling For Answers.' The Washington Post.com, The Washington Post. 9 Aug. (2004). Web. 30 Sep. 2014.

'Fertility Rate Total (Births Per Woman).' Worldbank.org. The World Bank. 2015. Web. 30 Jan. 2015.

Field, Norma. 'The Child as Laborer and Consumer: The Disappearance of Childhood in Contemporary Japan.' Children and the Politics of Culture. Ed. Sharon Stephens. Princeton: Princeton University Press, 1995. Print.

Figal, Gerald. Civilization and Monsters: Spirits of Modernity in Modern Japan. Durham: Duke University Press, 1999. Print.

Fletcher III, W. Miles and von Staden, Peter W. 'Epilogue: retrospect and prospects: the significance of the 'lost decades' in Japan.' Asia Pacific Business Review. 18.2 (2012): 275-279. Taylor and Francis Journals Complete. Web. 30 Sep. 2014.

Goodman, Roger. Children of the Japanese State: The Changing Role of Child Protection Institutions in Contemporary Japan. Oxford: Oxford University Press, 2000. Print. Hand, Richard J. 'Aesthetics of Cruelty: Traditional Japanese Theatre and the Horror Film.' Japanese Horror Cinema. Ed. Jay McRoy. Edinburgh: Edinburgh University Press, 2006. 18-29. Print.

Hearn, Lafcadio. Kwaidan: Stories and Studies of Strange Things. 1904. New York: Start Publishing LLC, 2012. Print.

Ikeda, Yoshiko. 'Child Abuse and Child Abuse Studies in Japan.' Pediatrics International 37.2 (1995): 240-247. Wiley Online Journal. Web. 30 Sep. 2014.

'Imperial Rescript on Education making slow, contentious comeback.' JapanTimes. co.jp, Japan Times. 12 April 2017. Web. 21 April 2017.

Igarashi, Yoshikuni. Bodies of Memory: Narratives of War in Postwar Japanese Culture, 1945-1970. Princeton: Princeton University Press, 2000. Print. 
'Japan PM Shinzo Abe visits Yasukuni WW2 Shrine.' BBC.com, BBC World News. 26 Dec. 2013. Web. 30 Sep. 2014.

Kakuchi, Suvendrini. 'Youth murder shocks Japan.' AsiaTimes.com, Asia Times. 15 July 2003. Web. 25 Oct. 2013.

Kawakami, Ryoichi. Gakkō Hōkai [School Collapse]. Tokyo: Bungei Shunju, 1999. Print. Kermode, Mark. 'Review of RIngu.' Sight and Sound, British Film Institute. Sep. 2000. Web. 30 Sep. 2014.

Kinoshita, Chika. 'The Mummy Complex: Kurosawa Kiyoshi's Loft and J-Horror.' Horror To the Extreme, Ed. Jinhee Choi and Mitsuyo Wada-Marciano. Hong Kong: Hong Kong University Press, 2009. 103-123. Print.

Lamb, Lynzee. 'Tokyo Theme Park Offering Creepy Sadako 3D 2 Menu.' Anime News Network, Anime News Network, 28 July 2013. Web. 30 Sep. 2014.

Landry, Jess. 'SADAKo 3D: Super Scary Fun Time Challenge Extreme! Part 1.' Dirge Magazine, Dirge Magazine. 21 April 2015. Web. 1 May 2015.

Lev, Michael A. 'Beheading Arrest Plunges Japan Into Despair About Its Kids.' ChicagoTribune.com, Chicago Tribune. 4 July 1997. Web. 30 Sep. 2014.

Lim, Bliss Cua. Translating Time: Cinema, the Fantastic and Temporal Critique. Durham: Duke University Press, 2009. Print.

Litke, Mark. 'Juvenile Crime No Longer Rare in Japan.' ABC News.com, American Broadcasting Corporation. 28 Nov. 2003. Web. 30 Sep. 2014.

Low, Morris. 'Technological Culture.' The Cambridge Companion to ModernJapanese Culture. Ed. Yoshio Sugimoto. Melbourne: Cambridge University Press, 2009. 130-146. Print.

Lowenstein, Adam. 'Ghosts in a Superflat Global Village: Globalization, Surrealism and Contemporary Japanese Horror Films.' Post-Script. 28.2 (2009): 59-72. EBSCO Host Humanities International Complete. Web. 30 Sep. 2014.

—.'Globalized Spectatorship: Ring Around the Superflat Global Village: J-Horror Between Japan and America.' Dreaming of Cinema: Spectatorship, Surrealism and the Age ofDigital Media. New York: Columbia University Press, 2015 · 79-116. Print.

-.Shocking Representation: Historical Trauma, National Cinema and the Modern Horror Film. New York: Columbia University Press, 2005. Print.

Lury, Karen. The Child in Film. London: I.B. Tauris \& Co. Ltd., 2010. Print.

McRoy, Jay, ed. 'Case Study: Cinematic Hybridity in Shimizu Takashi's Ju-ON: THE GRudge.' Japanese Horror Cinema. Edinburgh: Edinburgh University Press, 2005. 175-184. Print.

-.Nightmare Japan. Amsterdam: Rodopi, 2008. Print.

Muir, Bob. 'Latest SADAKO 3D marketing flooding the streets with Sadako.'Japanator, Modern Method. 5 Aug. 2012. Web. 30 Sep. 2014.

Nakamura, Naofumi. 'Railway Systems and Time Consciousness in Modern Japan.' Japan Review. 14 (2002): 13-38. JSTOR Arts and Sciences III. Web. 30 Sep. 2014. 
Napier, Susan. The Fantastic in Modern Japanese Literature. Tokyo: The Nissan Institute/Routledge Japanese Studies, 1995. Print.

Nasu, Masamoto. The Children of the Paper Crane: The Story of Sadako Sasaki and Her Struggle with A-Bomb Disease. Trans. Elizabeth W. Baldwin. London: Routledge, 1991. Print.

Ōe, Kenzaburō. 'Aghwee the Sky Monster.' 1964. Teach Us to Outgrow Our Madness. Trans. John Nathan. New York: Grove Press, 1994. 221-328. Print.

-.The Pinch Runner Memorandum. 1976. Trans. Michiko N. Wilson and Michael K. Wilson. London: Routledge. 1994. Print.

'Osaka Mayor Toru Hashimoto: Sex slaves in World War Two were necessary to "maintain discipline" for Japanese army.' The Independent.co.uk, The Independent UK. 14 May 2013. Web. 30 Sep. 2015.

Phu, Thy. 'Horrifying adaptations: RINGU, THE RING, and the cultural contexts of copying.' Journal of Adaptation in Film and Performance. 3.1 (2010): 43-58. Print.

Platt, Brian. 'Japanese Childhood, Modern Childhood: The Nation-State, the School,

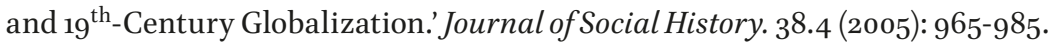
JSTOR Arts and Sciences VII. Web. 30 Sep. 2014.

Rauer, Julie. 'Persistence of a Genetic Scar: Japanese Anime, Manga, and Otaku Culture Fill an Open National Wound.' AsianArt.com: The on-line journal for the study and exhibition of the arts in Asia. 13 June 2005. n.p. Web. 30 Sep. 2014. Shin, Chi-Yu. 'The Art of Branding: Tartan "Asia Extreme" Films.' Horror to the Extreme: Changing Boundaries in Asian Cinema. Ed. Jinhee Choi and Mitsuyo Wada-Marciano. Hong Kong: Hong Kong University Press, 2009. 85-100. Print.

Sōseki, Natsume. Ten Nights' Dreams. 1908. Trans. Takumi Kashima and Loretta R. Lorenz. London: Soseki Museum in London, 2000. Print.

Stuchlíková, Zuzana. 'Japan's Lost Decade: On the Development of The Japanese Economy in the 1990s.' Journal of International Relations. 4 (2012): 129-152. HeinOnline Law Journal Library. Web. 30 Sep. 2014.

Suttmeier, Bruce. 'Speculations of Murder: Ghostly dreams, poisonous frogs and the case of Yokoi Shoichi.' Perversion and Modern Japan: Psychoanalysis, Literature, Culture. Ed. Nina Cornyetz and J. Keith Vincent. Oxon: Routledge, 2010. 22-39. Print.

Suzuki, Koji. Ring. Trans. Robert B. Rohmer and Glynne Walley. New York: Vertical, 2004. Print.

Tanaka, Stefan. 'Childhood: Naturalization of Development in a Japanese Space.' Cultures of Scholarship. Ed. Sarah C. Humphreys. Ann Arbor: The University of Michigan Press, 1997. 21-56. Print.

-.New Times in Modern Japan. Princeton: Princeton University Press, 2004. Print.

Tateishi, Ramie. 'The Japanese Horror Film Series: Ring and Eko Eko Azarak.' Fear Without Frontiers: Horror Cinema Across the Globe. Ed. Steven Jay Schneider. Godalming: FAB Press, 2003. Print. 
Trefalt, Beatrice. Japanese Army Stragglers and Memories of the War in Japan, 1950-75. London: RoutledgeCurzon, 2003. Print.

Uno, Kathleen. Passages to Modernity: Motherhood, Childhood, and Social Reform in Early Twentieth Century Japan. Honolulu: University of Hawai'i Press, 1999. Print. Wada-Marciano, Mitsuyo.Japanese Cinema of the Digital Age. Honolulu: University of Hawai'i Press, 2012. Print.

-.'J-Horror: New Media's Impact on Contemporary Japanese Horror Cinema.' Horror To the Extreme: Changing Boundaries in Asian Cinema. Ed. Jinhee Choi and Mitsuyo Wada-Marciano. Hong Kong: Hong Kong University Press, 2009. 15-39. Print.

Wee, Valerie.Japanese Horror Films and their American Remakes. London: Routledge, 2013. Print.

-.'Patriarchy and the Horror of the Monstrous Feminine: A Comparative Study of RIngu and The Ring.' Feminist Media Studies 11.02 (2011a): 151-165. Taylor and Francis Journals Complete. Web. 30 Sep. 2014.

-.'Visual Aesthetics and Ways of Seeing: Comparing Ringu and THE Ring.' Cinema Journal 50.2 (2011b): 41-6o. JSTOR Arts and Sciences III. Web. 30 Sep. 2014.

Weinstein, David E., Kashyap, A. K., and Hamada, Kōichi.Japan's Bubble, Deflation and Long-term Collapse. Cambridge: MIT Press, 2011. Print.

Wetsch, Elisabeth. 'Kobe School Killer.' Crimezzz.net, Elisabeth Wetsch. 2005. Web. 30 Sep. 2014.

Wood, Christopher. The bubble economy: The Japanese economic collapse. London: Sidgwick and Jackson, 1992. Print.

Yoneyama, Lisa. Hiroshima Traces: Time, Space and the Dialectics of Memory. Berkeley: University of California Press, 1999. Print.

\section{Filmography}

Ghost Story of Yotsuya [Tôkaidô Yotsuya KaIdAn]. Dir. Nobuo Nakagawa. Shintoho Film Distribution Committee, 1959. Film.

The Grudge. Dir. Takashi Shimizu. Sony Pictures Home Entertainment, 2005. DVD. Hara-Kiri: Death of A SAMurai [ICHIMEI]. Dir. Takashi Miike. Sedic International, 2011. Film.

Ju-ON: The Grudge [Ju-ON]. Dir. Takashi Shimizu. 2002. Lionsgate Home Entertainment, 2005. DVD.

KWAIDAN [KaIdAn]. Dir. Masaki Kobayashi. Bungei, 1964. Film.

On a Paper Crane: Tomoko's Adventure [Tsuru ni notte: Tomoko no bouken].

Dir. Arihara Seiji. Peace Anime, 1994. VHS Videotape.

Onibaba. Dir. Kaneto Shindô. Kindai Eiga Kyokai, 1964. Film. 
Princess Mononoke [Mononoke-Hime]. Dir. Hayao Miyazaki. Studio Ghibli, 1997. Film.

RINGU. Dir. Hideo Nakata. 1998. DreamWorks Video, 2000. DVD.

RINGU 2. Dir. Hideo Nakata. 1999. DreamWorks Video, 2005. DVD.

The RING. Dir. Gore Verbinski. 2002. DreamWorks Pictures, 2013. Blu-ray DVD.

SADAKo 3 D. Dir. Tsutomu Hanabusa. Kadakowa Pictures, 2012. Film.

SADAKo 3D 2. Dir. Tsutomu Hanabusa. Kadakowa Pictures, 2013. Film.

Ugetsu [Ugetsu monogatari]. Dir. Kenji Mizoguchi. Daiei Studios, 1954. Film.

\section{Artworks}

Coerr, Eleanor. Sadako. Illust. Ed Young. New York: G.P. Putnam's Sons, 1993. Print.

-.Sadako and the Thousand Paper Cranes. 1977. New York: Puffin Books, 1999. Print.

Fg2. Children's Peace Monument. 2005. Photograph. Wikimedia Commons. Web. 30 Jan. 2015 .

Hongo, Shin. Statue of Mother and Children During the Storm. 1960. Bronze. Hiroshima Peace Park, Hiroshima City.

Ishikawa, Kouyou. Charred mother and child after the Operation Meetinghouse bombing. 1945. Photograph. C. Peter Chen, World War II Database. Web. 30 Sep. 2014 .

Kikuchi, Kazuo and Ikebe, Kiyoshi. Children's Peace Monument. 1958. Bronze and concrete. Hiroshima Peace Park, Hiroshima City.

Parker, Lewan. The Statue of Sadako Sasaki. 2015. Photograph.

Robertson, Corporal Angus. A Member of a Marine Patrol on Saipan found this family ofJaps hiding in a Hillside Cave. 1944. Photograph. National Archives and Records Administration, Archives.gov. Web. 30 Sep 2014. 
